\title{
HYDROXYCHLOROQUINE AND AZITHROMYCIN COMBINATION COULD BE LETHAL TO COVID-19 PATIENTS
}

\author{
FIRDOUS SAYEED MOHAMMAD *, VARNITA KARMAKAR ${ }^{\#}$, ZAINAB IRFAN ${ }^{\#}$ \\ Department of Pharmacology, Calcutta Institute of Pharmaceutical Technology \& AHS, Uluberia, Howrah 711316, West Bengal, India
}

*corresponding author: firdous.cology@gmail.com

${ }^{\#}$ Authors with equal contribution.

Manuscript received: May 2020

\begin{abstract}
With the advent of COVID-19 or the novel coronavirus and the pandemic outbreak, scientists around the globe are endeavoured to discover therapeutically efficacious drugs against the disease. Initial small-scale trials and studies have demonstrated the possible impact of the antimalarial drug hydroxychloroquine (HCQ) and antibiotic azithromycin (AZM) unaided or together can be productive in the management of coronavirus disease. However, the latest research stretches on serious implications such as irregularities in the heart electrical impulses, polymorphic ventricular tachycardia including torsade de pointes (TdP), and long QT syndrome (LQTS) associated with the use of these drugs. In the worst-case scenario, higher doses have been lethal to the patients treated with these drugs as per recent reports. To have a closer look over the safety considerations, this review is focused on the latest updates, research, and findings of the impact of HCQ and AZM in COVID-19 affected individuals with an emphasis on the pre-existing cardiovascular risk factors. Besides, this review also briefly compiles some of the major clinical trial case reports which can present evident data related to the clinical application of both the drugs along with its abnormal effect on cardiac rhythm.
\end{abstract}

\section{Rezumat}

O dată cu apariția COVID-19 și a focarului de pandemie, oamenii de știință se străduiesc să descopere medicamente eficiente împotriva bolii. Studiile inițiale și studiile la scară mică au arătat efectul hidroxiclorochinei (HCQ) și azitromicinei (AZM), singure sau în combinație, în tratamentul infecției cu SARS-CoV-2. Cu toate acestea, cele mai recente cercetări se referă la implicații grave, cum ar fi dezechilibre în impulsurile electrice ale inimii, tahicardie ventriculară polimorfă, inclusiv torsada vârfurilor și prelungirea intervalului QT. Această lucrare se axează pe cele mai recente actualizări, cercetări şi constatări ale impactului hidroxiclorochinei şi azitromicinei la pacienții cu COVID-19, cu accent pe factorii de risc cardiovasculari preexistenți. În plus, lucrarea sumarizează câteva dintre raportările majore ale studiilor clinice care prezintă date concrete în contextul utilizării acestor medicamente.

Keywords: COVID-19, hydroxychloroquine, azithromycin, long QT syndrome (LQTS), torsade de pointes (TdP), case reports

\section{Introduction}

The emergence as well as the revival of pathogens is a revolutionary global threat for the entire healthcare section over the society. One such global challenge, a breakout of pneumonia provoked by novel coronavirus was reported on December 8, 2019, in Wuhan, Hubei province, China [1]. The World Health Organization (WHO) after the identification plus isolation of the virus officially named it as severe acute respiratory syndrome coronavirus 2 (SARS-CoV-2) which was initially recognized as 2019 novel coronavirus (2019nCOV) and declared it to be a Communal Health Catastrophe of Global concern on $30^{\text {th }}$ January 2020 [2]. The respiratory involvement is the foremost clinical indication of COVID-19, nevertheless, the preceding heart disorder and cardiovascular risk factors in a patient positive for COVID-19 can worsen the underlying cardiovascular disease which might escalate the risk of death [3].
Many drugs are currently being tested which include antiviral (remdesivir, favipiravir, lopinavir, ritonavir and arbidol), anti-malarial (HCQ) and anticancer (interferon-alpha 2b) agents. HCQ solely and in combination with AZM can be an effective medication for COVID-19 has been suggested by in vitro and preliminary clinical research [4]. However, chloroquine (CQ), HCQ and AZM delay QT interval which increases the chance of cardiac arrhythmia of an individual [5]. Hence, this review is aimed to provide information on untoward cardiac outcomes of HCQ and AZM combination in COVID-19 subjects.

\section{How COVID-19 triggers cardiovascular risk?}

Initially, it was reported that the primary target for the SAR-CoV-2 is the respiratory tract but the recent cohort study [4] reports that many serious cardiovascular complications might also occur. A COVID19 positive patient with pre-existing cardiac disease may endure a cardiac arrest or congestive heart failure. 
A blend of intense viral sickness and its expanded request on the heart, for instance, fever causing quick heart rate, intensified by inadequate oxygen levels because of pneumonia as well as an expanded affinity for blood coagulation development worsens the cardiovascular health of an individual affected with COVID19 with pre-existing cardiac ailment [6]. COVID-19 patients suffering from cardiac complications are rather experiencing pronounced inflammation of the cardiac muscle, called myocarditis. These victims when underwent electrocardiograms and blood tests indicated changes of a significant heart attack and increased level of the enzyme present in the heart, troponin, which is discharged when the cardiac muscle is harmed [7].

There is also an increased risk in patients suffering from hypertension and coronary artery disease who might die of COVID-19. For the therapy of hypertension both Angiotensin-Converting Enzyme (ACE) inhibitors and Angiotensin Receptor Blockers (ARB) are mostly prescribed which increases the occurrence of COVID-19 in hypertensive patients as observed that the SAR-CoV-2 attaches to angiotensin-converting enzyme 2 receptor [8]. ACE2 receptor, mainly found in lungs and heart tissue, performs a notable function in the neurohumoral regulation of the cardiovascular system which can alter the ACE2 signalling pathways when SARS-CoV-2 attaches to ACE2 causing acute myocardial as well as lung injury $[9,10]$.

Also, the communication of SARS-CoV-2 with the rennin-angiotensin-aldosterone system leads to hypokalaemia which in turn escalates the risk to distinctive tachyarrhythmias [11]. Studies have also been reported of high circulatory levels of acute systemic inflammatory response and cytokines leading to multiorgan failure of being characteristics of severe or critical forms of COVID-19 patients [3, 12].

\section{Drugs for COVID-19}

Presently, there is no confirmation of potential medication for individuals with either doubtful or confirmed COVID-19. Presently, drugs that have been used during the SARS and MERS outbreak are the probable successor for medicating COVID-19 $[13,14]$. The significant proposed drugs, repurposed or experimental, for COVID-19 are CQ and HCQ, lopinavir or ritonavir, remdesivir, favipiravir, immunomodulatory agents, and immunoglobulin therapy.

CQ and HCQ are the significant medicaments utilized in the prevention and therapy of malaria and chronic inflammatory diseases such as systemic lupus erythematosus (SLE) and rheumatoid arthritis (RA) [15]. By inhibiting the glycosylation of host receptors, proteolytic processing, and endosomal acidification, CQ and HCQ seem to block the viral entry into the cells. Through the weakening of cytokine synthesis as well as the hindrance of autophagy and lysosomal activity in host cells, they additionally possess immuno- modulatory effects $[16,17]$. With a half-maximal efficient concentration $\left(\mathrm{EC}_{50}\right)$ in the low micro-molar range, CQ suppresses SARS-CoV-2 in vitro whereas when compared with CQ after 24 hours of growth, $\mathrm{HCQ}$ has in vitro activity with a lower $\mathrm{EC}_{50}$ for SARS-CoV-2 (HCQ: $\mathrm{EC}_{50}=6.14 \mu \mathrm{M}$ and CQ: $\mathrm{EC}_{50}=23.90 \mu \mathrm{M}$ ) [18]. Currently, both CQ and HCQ are under a randomized clinical trial for investigating their role in the management of COVID-19. Besides, combination HCQ with AZM has been divulged to be an efficient medicament for COVID-19 patients as suggested by preliminary clinical studies. However, this combination could be lethal in COVID-19 patients as it causes a change in the rhythm of the heart [4].

For the management of COVID-19, initial reports of lopinavir are mostly small retrospective, non-randomized cohort studies as well as case reports which make it hard to determine the immediate treatment effect of lopinavir. The present data indicate a limited function of lopinavir in COVID-19 treatment although RCTs of lopinavir are ongoing [19, 20].

Another potential class of therapy for COVID-19 is the immunomodulatory agents and plasma therapy.

\section{Hydroxychloroquine and QT prolongation}

The irregular repolarization of the ventricular myocardium which leads to prolongation of the QT interval on the electrocardiogram is known as the QT prolongation [21-23]. The unconsciousness as well as unforeseen cardiac death from an inevitable cardiac arrhythmia known as TdP, a manifestation of manifold ventricular tachycardia with a heart rate more than 100 beats per minute with marked change over the isoelectric baseline every 5 - 20 beats, is the clinical feature of the prolonged QT interval $[24,25]$. In a study, it has been reported that the use of HCQ is linked with QT interval lengthening, and the use of mexiletine decreases the QT interval by reducing the plateau phase of the myocardial nerve impulse thereby accelerating repolarization rates [26]. For the management of Systemic lupus erythematosus (SLE), HCQ is recommended as the first-line therapy and thus is important for the patients on chronic therapy to timely monitor the QT interval $[27,28]$. Because of the excess or exceptional metabolism in patients with liver or renal defect, increase blood concentration of HCQ occurs which has been reported to be associated with the QT prolongation. Thus, alternative treatment should be considered for patients suffering from kidney and liver impairment as they are at the topmost risk for QT lengthening and arrhythmias [29].

\section{Azithromycin and QT prolongation}

AZM, a wide-spectrum macrolide, is prescribed for the therapy of respiratory and urinary tract bacterial contamination. Many cases describing QT-interval prolongation, TdP, and manifold ventricular tachycardia have been disclosed following the utilization of AZM. 
Also, conflicting results have been reported in connection with the linkage amid AZM use and cardiovascular death in many observational studies [30]. The US Food and Drug Administration delivered a safety cautionary about the possibilities for AZM to give rise to unusual development in the electrical motion of the heart i.e. related to cardiovascular death. They also recommended healthcare experts that when taking into account the treatment choices for patients who are previously at danger for cardiovascular consequences; they should monitor the possibility of TdP and catastrophic heart rhythms and additionally noting the probable prospect of QT prolongation with AZM when selecting an antibacterial drug [31]. It has also been reported that AZM was linked with the elevated risk of ventricular arrhythmia when correlated with no utilization of antibiotics however not when amoxicillin was used [30].

\section{Clinical studies of Hydroxychloroquine and Azithromycin on COVID-19 patients}

As the COVID-19 turns out to be the worst worldwide pandemic urging the global rage, the fight to cure this pernicious disease is the need of this hour. Since the number of COVID-19 incidents and deaths growing with each passing day, pandemic physicians have started to find safe and efficient treatments to avoid SARS-CoV-2 infections and also, to minimize the severity of the subsequent COVID-19 respiratory disease [11, 32]. Although there are no medications approved by the Food and Drug Administration (FDA) to fend off or treat COVID-19, some "re-purposed" medications such as HCQ and AZM are tested in numerous randomized control clinical trials [33].

An in vitro antiviral activity demonstrated by Yao et al. showed a significant inhibitory action of HCQ and CQ against SARS-CoV-2 [18]. In clinical trials, chloroquine phosphate has shown ostensible efficacy in the treatment of Chinese COVID-19 related pneumonia patients by reducing the viral load and preventing disease progression [34]. Followed by this, another preliminary clinical trial conducted in a small cohort of COVID-19 affected patients found that 70 percent of patients tested negative for the virus by nasopharyngeal PCR while administered with HCQ (600 mg daily), compared to just 12.5 percent of patients who tested negative for D6-post inclusion PCR controls. Thus, this has led the Chinese specialists to believe in CQ dependent therapy (500 mg twice daily for 10 days) as a first line-treatment for COVID-19 [4]. While in contrast, a recent report from China revealed that people affected with COVID-19 found no substantial difference in the intensity of virologic load at 7 days irrespective of 5 days of $400 \mathrm{mg}$ HCQ treatment. Also, no change in clinical consequences such as hospitalization period, temperature stabilization, and radiological development was observed [11]. Besides, another initial small-scale research in France conducted a prospective virologic study in 11 consecutive COVID19 patients using the same regimen (HCQ $600 \mathrm{mg}$ daily for 10 successive days and AZM $500 \mathrm{mg}$ for day 1 and $250 \mathrm{mg}$ for next days 2 to 5 days) as reported earlier in Gautret et al. The study showed no affirmation of quick clearance of viral load or therapeutic gain in patients with serious COVID-19 infection with the use of the combination of HCQ and AZM [4, 35]. An alternative study, published on medRxiv, showed Chinese researchers at Wuhan University's Renmin Hospital, performed an open level randomized Clinical trial with HCQ administration to COVID-19 patients with only mild infections free of medical issues, parallel to the Gautrets' research. The findings indicated that the 31 patients receiving the medication displayed a 24-hour faster reduction of their symptoms than patients in the control group. The report partly confirms the HCQ's capability in COVID-19 therapy [11].

The latest controlled, double-blinded, clinical trial studies from Brazil suggested that a higher dosage of HCQ could be lethal. The researchers studied in a city hospital in Manaus two classes of COVID-19 patients; the high-dose group obtained a total dose of 12 grams of CQ over 10 consecutive days, whereas the low-dose community obtained a total dose of 2.7 grams over 5 days. Both participants were also given ceftriaxone and AZM antibiotics. Further study was alarmingly stopped due to reported deaths specifically in the group randomized to receive higher doses of the drug [36].

Moreover, a recent news report by Rediff.com proposal proclaimed that the to use HCQ for the treatment of COVID-19 patients in the United States has faltered with further deaths of patients who were being prescribed the highly-touted anti-malarial medication. According to this report, the National Institute of Health (NIH) noted in a statement that therapeutic options are subject to investigation and that absence of empirical information makes it difficult to suggest whether to propose or resist the utilization of CQ or HCQ for COVID-19 treatment. The NIH panel experts recommended limited use of the blend of HCQ and AZM due to the extreme toxicity risk [37].

According to guidance from the American Heart Association (AHA), the American College of Cardiology (ACC), and the Heart Rhythm Society (HRS), based on post-marketing adverse event reports, both drugs are considered to prolong the QT length along with critical rhythmic irregularities in the heart such as arrhythmia (irregular heartbeat), polymorphic ventricular tachycardia, TdP and elevated risk of sudden death [38]. HRS President and co-author Andrea Russo suggested careful attention and monitoring safeguard high-risk patients with cardiovascular disease [39]. Since there are very few studies assessing the efficacy of combination treatment, multiple randomized controlled 
FARMACIA, 2020, Vol. 68, 3

trials (more than 90) are required to validate both the therapeutic ability and safety concerns.
An overview of major safety outcome studies carried out using HCQ/CQ and AZM for treatment of COVID19 is presented in Table I.

Table I

An overview of major safety outcome studies carried out using HCQ/ CQ and AZM for treatment of COVID-19

\begin{tabular}{|c|c|c|c|c|c|}
\hline Study type & Country & $\begin{array}{l}\text { Total no. of } \\
\text { participant }\end{array}$ & Dosage & Safety outcome & References \\
\hline $\begin{array}{l}\text { Randomized } \\
\text { double- } \\
\text { blinded, } \\
\text { Clinical trial } \\
\text { (Phase IIb) }\end{array}$ & $\begin{array}{l}\text { Hospital e } \\
\text { Pronto-Socorro } \\
\text { Delphina } \\
\text { Rinaldi Abdel } \\
\text { Aziz, Manaus, } \\
\text { Brazil }\end{array}$ & 440 & $\begin{array}{c}\text { High dose CQ ( } 600 \mathrm{mg} \\
2 \text { times daily for } 10 \text { days } \\
\text { or } 12 \mathrm{~g} \text { gross dosage); or } \\
\text { Lower dose of CQ ( } 450 \\
\mathrm{mg} \text { for } 5 \text { days or total } \\
\text { dose } 2.7 \mathrm{~g}) .\end{array}$ & $\begin{array}{c}\text { The group with high dosage CQ } \\
\text { showed more QTc }>500 \mathrm{~ms}(18.9 \%) \text {, } \\
\text { and drift toward higher lethality } \\
(39 \%) \text { than the lower dosage. }\end{array}$ & [36] \\
\hline $\begin{array}{c}\text { Retrospective } \\
\text { study }\end{array}$ & $\begin{array}{l}\text { NYU Langone } \\
\text { medical center, } \\
\text { New York, USA }\end{array}$ & 84 & HCQ/AZM combination & $\begin{array}{c}\text { In } 30 \% \text { of patients, QTc prolonged by } \\
\text { more than > } 40 \text { ms. While, } 11 \% \text { of } \\
\text { patients showed QTc increased to } \\
>500 \text { ms, representing a high-risk for } \\
\text { arrhythmia. } \\
\end{array}$ & [40] \\
\hline $\begin{array}{l}\text { Prospective } \\
\text { study }\end{array}$ & $\begin{array}{l}\text { AP-HP-Saint- } \\
\text { Louis Hospital, } \\
\text { Claude- } \\
\text { Vellefaux, Paris, } \\
\text { France }\end{array}$ & 11 & \begin{tabular}{|} 
HCQ (600 mg once \\
daily for 10 days) and \\
AZM (500 mg for day 1 \\
and $250 \mathrm{mg}$ for next 2 to \\
5 days $)$
\end{tabular} & $\begin{array}{c}\text { One patient died within } 5 \text { days, and } \\
\text { two were admitted to the ICU. HCQ } \\
\text { and AZM were stopped in one patient } \\
\text { after } 4 \text { days due to a prolongation of } \\
\text { the QT interval from } 405 \mathrm{~ms} \text { before } \\
\text { diagnosis to } 460 \text { and } 470 \mathrm{~ms} \text { due to } \\
\text { the combination therapy. }\end{array}$ & {$[35]$} \\
\hline $\begin{array}{l}\text { Adverse event } \\
\text { reporting } \\
\text { from post- } \\
\text { marketing } \\
\text { surveillance } \\
\end{array}$ & $\begin{array}{c}\text { Mayo Clinic, } \\
\text { Rochester, USA }\end{array}$ & -- & HCQ/AZM combination & $\begin{array}{c}\text { Lengthen the heart rate corrected QT } \\
\text { interval (QTc), thus increases the risk } \\
\text { of drug-induced TdP, and sudden } \\
\text { cardiac failure. }\end{array}$ & {$[32]$} \\
\hline $\begin{array}{c}\text { Pilot } \\
\text { observational } \\
\text { study }\end{array}$ & $\begin{array}{l}\text { University } \\
\text { Hospital } \\
\text { Institute } \\
\text { Mediterranee } \\
\text { Infection, } \\
\text { Marseille, } \\
\text { France }\end{array}$ & 80 & $\begin{array}{c}\text { Combination of } 200 \mathrm{mg} \\
\text { of } \mathrm{HCQ} \text {, thrice daily for } \\
10 \text { consecutive days } \\
\text { with AZM, } 500 \mathrm{mg} \text { on } \\
\text { day } 1 \text { followed by } 250 \\
\text { mg once daily for the } \\
\text { next } 4 \text { days }\end{array}$ & $\begin{array}{l}\text { The majority of patients }(65 / 80,81.3 \\
\text { percent) demonstrated positive or } \\
\text { favourable results. The risk-benefit } \\
\text { ratio was calculated by tracking the } \\
\text { variations of the electrocardiogram } \\
\text { and stopped when major anomalies } \\
\text { were detected. }\end{array}$ & [41] \\
\hline
\end{tabular}

\section{Conclusions}

In summary, despite some partial potential of HCQ and AZM in the COVID-19 therapy has been confirmed in a few case studies, yet the detrimental effects of both the drugs cannot be fully neglected. In fact, without proper scientific monitoring of the serious adverse reactions, the combination can have a disastrous impact. However, considering there is no better option at present, reasonable management with careful surveillance strategy can become promising for significantly reducing drug-induced ventricular or cardiac arrhythmias and sudden cardiac abnormalities with the use of these drugs. Besides, the Food and Drug Administration (FDA) of the United State also cautions about the use of HCQ unaided or in combination with any medicine likely known to cause QT prolongation, including AZM, which is being used in COVID-19 patients without FDA approval for this condition. In the meantime, there is a hope that ongoing large-scale clinical trials and extensive research work carried out throughout the globe will enable the innovation in the treatment strategies, rendering the development of high efficacy drugs combating COVID-19.

\section{Conflict of interest}

The authors declare no conflict of interest.

\section{References}

1. Wu Z, McGoogan JM, Characteristics of and important lessons from the coronavirus disease 2019 (COVID19) outbreak in China: summary of a report of 72314 cases from the Chinese center for disease control and prevention. J Am Med Assoc., 2020; 323(13): 1239-1242.

2. Zhou P, Yang XL, Guang WX, Hu B, Zhang L, Zhang W, Si HR, Zhu Y, Li B, Huang CL, Chen HD, Chen J, Luo Y, Guo H, Jiang RD, Liu MQ, Chen Y, Shen XR, Wang X, Zheng XS, Zhao K, Chen QJ, Deng F, Liu LL, Yan B, Zhan FX, Wang YY, Xiao GF, Shi ZL, A pneumonia outbreak associated with a new coronavirus of probable bat origin. Nature, 2020; 579(7798): 270-273.

3. Huang C, Wang Y, Li X, Ren L, Zhao J, Hu Y, Zhang L, Fan G, Xu J, Gu X, Cheng Z, Yu T, Xia J, 
Wei Y, Wu W, Xie X, Yin W, Li H, Liu M, Xiao Y, Gao H, Guo L, Xie J, Wang G, Jiang R, Gao Z, Jin Q, Wang J, Cao B, Clinical features of patients infected with 2019 novel coronavirus in Wuhan, China. Lancet, 2020; 395(10223): 497-506.

4. Gautret P, Lagier JC, Parola P, Hoang VT, Meddeb L, Mailhe M, Doudier B, Courjon J, Giordanengo V, Vieira VE, Dupont HT, Honoré S, Colson P, Chabrière E, La Scola B, Rolain JM, Brouqui P, Raoult D, Hydroxychloroquine and Azithromycin as a treatment of COVID-19: results of an open-label nonrandomized clinical trial. Int J Antimicrob Agents, 2020; doi: 10.1016/j.ijantimicag.2020.105949.

5. Simpson TF, Kovacs RJ, Stecker EC, Ventricular Arrhythmia risk due to HydroxychloroquineAzithromycin treatment for COVID-19. Cardiol Mag., 2020; 1-9.

6. Lewis DKL, How does cardiovascular disease increase the risk of severe illness and death from COVID-19?. Harvard Health Blog, 2020; www.health.harvard.edu.

7. Wang D, Hu B, Hu C, Zhu F, Liu X, Zhang J, Wang B, Xiang H, Cheng Z, Xiong Y, Zhao Y, Li Y, Wang X, Peng Z, Clinical characteristics of 138 hospitalized patients with 2019 novel coronavirusinfected pneumonia in Wuhan, China. JAMA., 2020; 323(11): 1061-1069.

8. Zheng YY, Ma YT, Zhang JY, Xie X, COVID-19 and the Cardiovascular system. Nature Rev Cardiol., 2020; 17: 259-260.

9. Xiong TY, Redwood S, Prendergast B, Chen M, Coronaviruses and the cardiovascular system: acute and long-term implications. Eur Heart J., 2020; 41(19): 1798-1800.

10. Li B, Yang J, Zhao F, Zhi L, Wang X, Liu L, Bi Z, Zhao Y, Prevalence and impact of cardiovascular metabolic diseases on COVID-19 in China. Clin Res Cardiol., 2020; 109(5): 531-538.

11. Chen D, Li X, Song Q, Hu C, Su F, Dai J, Hypokalemia and clinical implications in patients with coronavirus disease 2019 (COVID-19). MedRxiv, 2020; doi: https://doi.org/10.1101/2020.02.27. 20028530.

12. Zhou F, Yu T, Du R, Fan G, Liu Y, Liu Z, Xiang J, Wang Y, Song B, Gu X, Guan L, Wei Y, Li H, Wu $\mathrm{X}, \mathrm{Xu}$ J, Tu S, Zhang Y, Chen H, Cao B, Clinical course and risk factors for mortality of adult inpatients with COVID-19 in Wuhan, China: a retrospective cohort study. Lancet, 2020; 395(10229): 1054-1062.

13. Stockman LJ, Bellamy R, Garner P, SARS: systematic review of treatment effects. PLoS Med., 2006; 3(9): $1-7$.

14. Arsene AL, Dumitrescu IB, Drăgoi CM, Udeanu DI, Lupuliasa D, Jinga V, Drăgănescu D, Dinu-Pîrvu CE, Burcea Dragomiroiu GTA, Blejan IE, Moisi RE, Nicolae AC, Moldovan H, Popa DE, Velescu BS, Ruță S, A new era for the therapeutic management of the ongoing COVID-19 pandemic. Farmacia, 2020; 68(2): 185-196.

15. Savarino A, Boelaert JR, Cassone A, Majori G, Cauda $\mathrm{R}$, Effects of Chloroquine on viral infections: an old drug against today's diseases?. Lancet Infect Dis., 2003; 3(11): 722-727.

16. Zhou D, Dai SM, Tong Q, COVID-19: a recommendation to examine the effect of hydroxychloroquine in preventing infection and progression. J Antimicrob Chemother., 2020; doi: 10.1093/jac/dkaa114.

17. Devaux CA, Rolain JM, Colson P, Raoult D, New insights on the antiviral effects of chloroquine against coronavirus: what to expect for COVID-19?. Int $J$ Antimicrob Agents., 2020; doi: 10.1016/j.jjantimicag. 2020.105938.

18. Yao X, Ye F, Zhang M, Cui C, Huang B, Niu P, Liu X, Zhao L, Dong E, Song C, Zhan S, Lu R, Li H, Tan $\mathrm{W}$, Liu $\mathrm{D}$, In vitro antiviral activity and projection of optimized dosing design of hydroxychloroquine for the treatment of severe acute respiratory syndrome coronavirus 2 (SARS-CoV-2). Clin Infect Dis., 2020; doi: 10.1093/cid/ciaa237.

19. Yao TT, Qian JD, Zhu WY, Wang Y, Wang GQ, A systematic review of lopinavir therapy for SARS coronavirus and MERS coronavirus - A possible reference for coronavirus disease-19 treatment option. J Med Virol., 2020; 92(6): 556-563.

20. Chan KS, Lai ST, Chu CM, Tsui E, Tam CY, Wong MM, Tse MW, Que TL, Peiris JS, Sung J, Wong VC, Yuen KY, Treatment of severe acute respiratory syndrome with lopinavir/ritonavir: a multicentre retrospective matched cohort study. Hong Kong Med J., 2003; 9(6): 399-406.

21. Moss AJ, Long QT syndrome. J Am Med Assoc., 2003; 289(16): 2041-2044.

22. Li H, Fuentes-Garcia J, Towbin JA, Current concepts in long QT syndrome. Pediatr Cardiol., 2000; 21(6): 542-550.

23. Jackman WM, Friday KJ, Anderson JL, Aliot EM, Clark M, Lazzara R, The long QT syndrome: a critical review, new clinical observations and a unifying hypothesis. Prog Cardiovasc Dis., 1988; 31(2): 115-172.

24. El-Sherif N, Turitto G, Torsade de Pointes. Curr Opin Cardiol., 2003; 18(1): 6-13.

25. Passman R, Kadish A, Polymorphic ventricular tachycardia, long Q-T syndrome, and torsades de pointes. Med Clin North Am., 2001; 85(2): 321-341.

26. Monk JP, Brogden RN, A review of its pharmacodynamic and pharmacokinetic properties, and therapeutic use in the treatment of arrhythmias. Drugs, 1990; 40(3): 374-411.

27. Tett $\mathrm{S}$, Cutler D, Day R, Antimalarials in rheumatic diseases. Baillieres Clin Rheumatol., 1990; 4(3): 467-489.

28. Jones SK, Ocular toxicity and hydroxychloroquine: guidelines for screening. $\mathrm{Br} J$ Dermatol., 1999; 140(1): 3-7.

29. O'Laughlin JP, Mehta PH, Wong BC, Life threatening severe QTc prolongation in patient with systemic lupus erythematosus due to hydroxychloroquine. Case Rep Cardiol., 2016; 2016: 1-4.

30. Trifiro G, de Ridder M, Sultana J, Oteri A, Rijinbeek P, Pecchioli S, Mazzaglia G, Bezemer I, Garbe E, Schink T, Poluzzi E, MolokhiaM, Diemberger I, Sturkenboom MCJM, Use of Azithromycin and risk of ventricular arrhythmia. Can Med Assoc J., 2017; 189(15): E560-E568.

31. FDA statement regarding Azithromycin (Zithromax) and the risk of cardiovascular death. Silver Spring (MD): US Food and Drug Administration, 2012; www.fda.gov. 
32. Giudicessi JR, Noseworthy PA, Friedman PA, Ackerman MJ, Urgent Guidance for Navigating and Circumventing the QTc Prolonging and Torsadogenic Potential of Possible Pharmacotherapies for COVID19. Mayo Clin Proc., 2020; doi: org/10.1016/j.mayocp. 2020.03.024.

33. Wang M, Cao R, Zhang L, Yang X, Liu J, Xu M, Shi Z, Hu Z, Zhong W, Xiao G, Remdesivir and chloroquine effectively inhibit the recently emerged novel coronavirus (2019-nCoV) in vitro. Cell Res., 2020; 30(3): 269-271.

34. Gao J, Tian Z, Yang X, Breakthrough: chloroquine phosphate has shown apparent efficacy in treatment of COVID-19 associated pneumonia in clinical studies. Biosci Trends., 2020; 14(1): 72-73.

35. Molina JM, Delaugerre C, Goff JL, Mela-Lima B, Ponscarme D, Goldwirt L, de Castro N, No evidence of rapid antiviral clearance or clinical benefit with the combination of Hydroxychloroquine and Azithromycin in patients with severe COVID-19 infection. Med Mal Infect., 2020; doi: 10.1016/j.medmal.2020.03.006.

36. Borba MGS, Val FFA, Sampaio VS, Alexandre MAAA, Melo GC, Chloroquine diphosphate in two different dosages as adjunctive therapy of hospitalized patients with severe respiratory syndrome in the context of coronavirus (SARS-CoV-2) infection: Preliminary safety results of a randomized, double-blinded, phase IIb clinical trial (CloroCovid-19 Study). meRxiv, 2020; doi: https://doi.org/10.1101/2020.04.07.20056424.
37. Jha LK, Hydroxychloroquine doesn't help treat COVID-19: Report, available at: www.rediff.com/.

38. Roden DM, Harrington RA, Poppas A, Russo AM, Considerations for Drug Interactions on QTc in Exploratory COVID-19 (Coronavirus Disease 2019) Treatment. Circulation, 2020; doi: 10.1161/circulationaha. 120.047521.

39. Lau N, Heart Groups: Clear Risks with Hydroxychloroquine for COVID-19: AHA/ACC/HRS caution on malaria drug plus antibiotic. 2020; www.medpagetoday.com.

40. Chorin E, Dai M, Shulman E, Wadhwani L, Cohen RB, Barbhaiya C, Aizer A, Holes D, Bernstein S, Soinelli M, Park DD, Chinitz L, Jankelosn L, The QT Interval in Patients with SARS-CoV-2 Infection Treated with Hydroxychloroquine/Azithromycin. medRxiv., 2020; doi: 2020.04.02.20047050.

41. Gautret P, Lagier JC, Parola P, Hoang VT, Meddeb L, Sevestre J, Mailhe M, Doudier B, Aubry C, Amrane S, Seng P, Hocquart M, Eldin C, Finance J, Vieira VE, Tissot-Dupont HT, Honor S, Stein A, Million M, Colson P, Scola BL, Veit V, Jacquier A, Deharo JC, Drancourt M, Fournier PE, Rolain JM, Brouqui $\mathrm{P}$, Raoult D, Clinical and microbiological effect of a combination of Hydroxychloroquine and Azithromycin in 80 COVID-19 patients with at least a six-day follow up: an observational study. Int J Antimicrob Agents., 2020; doi: https://doi.org/10.1016/j.tmaid. 2020.101663. 